\title{
Reflections on the Society's History: A Memorial to John M. Virgo
}

\author{
Ralph W. Pfouts
}

Published online: 6 August 2013

(C) International Atlantic Economic Society 2013

The news of John Virgo's death saddened me greatly. He was a good friend, and the death of a friend is always depressing. But John represented more than friendship. He was a man who had done something that was very rare; it was in fact almost unique.

Many economists were interested in doing research and research was needed, but getting it published or verbally presented was difficult. Thus, a good deal of economic research was not made known. This also discouraged additional research.

Like most economists, John was aware of this situation. But unlike most economists, he decided to do something about it. He organized a group of economists who held meetings at which the results of economic research were made known, and they published a research journal. Indeed, they ultimately ended up publishing two research journals. The organization was known as the Atlantic Economic Society. It later became known as the International Atlantic Economic Society.

The word "International" was richly deserved because John expanded the activities of the Society to include European meetings. The European membership became large and active, served as officers of the Society, presented research findings at meetings, and published research in the journals.

Since I am a charter member of the Society, perhaps it would be appropriate for me to offer a few memories of the earliest days of the Atlantic Economic Society. The first indication of the Society that I had came through the mail. It was a mimeographed invitation to attend the first meeting of the Atlantic Economic Society, which would be held at the Federal Reserve Bank of Richmond.

Thus, the Society held its first meeting at the Richmond Fed. I am sure of this because I remember asking a very young member if he had seen the "discount window." The joke was on me because he actually wanted to see the discount window. Of course, there is no actual discount window; it is a verbal expression.

John ran the meetings very pleasantly and very effectively. The Society was officially organized. Officers were chosen. John was elected President, other officers

Ralph W. Pfouts is an Emeritus Professor at the University of North Carolina at Chapel Hill, Chapel Hill, NC, USA.

R. W. Pfouts $(\triangle)$

Boise, ID, USA

e-mail: rwpfouts@msn.com 
and members of the Board of Directors were chosen. I believe the Atlantic Economic Journal was organized at this meeting. I think that another meeting at which research papers would be presented was also planned. I was a member of the Board of Directors of the Atlantic Economic Society and the Board of Editors of the Atlantic Economic Journal.

John displayed an executive talent. He presented well thought out plans at the meeting, and he chose appropriate people for the various positions. He made it easy for an intelligent Board member to vote in favor of the plans that he, John, presented. The manner in which the plans were presented encouraged acceptance and prevented difficulties and bad feelings.

John had another way of acting that helped him. I will give an example. A few years ago, I attended one of the IAES meetings. When I arrived, John told me that his parents were attending the meeting, and he was planning a dinner for them and for a few friends of his. He invited me to attend. On the designated evening, I went to the site of the dinner and was told that I should sit next to John's father. I did, and at dinner I told Mr. Virgo about the unique accomplishments of his son in organizing and developing the Society. He was clearly pleased.

When I saw John the next day, I told him what I had told his father. John did not smile but said, "Yes, that's why I asked you to sit with him." A good executive always knows the best way to make use of a person's talents. John had this ability. Like a strong man's strength, it should be used with restraint, and John used it that way.

The institutions that John founded and developed will live on without him. Nobody can explain why God, Heaven, Fate, or pure chance sometimes causes the early departure of significant persons. Sometimes it happens, and sometimes it does not. All that anyone can do is to strengthen himself and do his best. 